Vol. 6, No. 2, October 2018, pp. 38 41

\title{
Strategi Pengembangan Museum Benteng Vredeburg Yogyakarta Sebagai Media Komunikasi Pendidikan
}

\author{
Hana Pradita ${ }^{1}$ \\ ${ }^{1}$ Program Studi Ilmu Komunikasi, Universitas Ahmad Dahlan, Indonesia
}

\begin{tabular}{l}
\hline \hline Article Info \\
\hline Article history: \\
Received Apr 17, 2018 \\
Accepted Aug 3, 2018
\end{tabular}

\section{Keywords:}

Strategi Pengembangan

Komunikasi

Pendidikan

\begin{abstract}
Penelitian ini bertujuan untuk mendeskripsikan bagaimana Strategi pengembangan yang dimiliki Museum Benteng Vredebrug Yogyakarta kurang berkompeten, sehingga kurangnya perawatan fasilitas yang ada di Museum Benteng Vrederburg Yogyakarta.

Jenis penelitian yang digunakan adalah Metode deskriptif kualitatif. Data-data yang diperoleh dari membandingkan data hasil pengamatan dengan hasil wawancara, observasi dan dokumentasi. Membangdingkan hasil wawanvcara dengan isi suatu dokumen yang berkaitan, membandingkan hasil wawancara dengan isi dokumen yang sudah diperoleh peneliti baik itu dari pihak Museum benteng Vredeburg Yogyakarta dan beberapa data, sumber lain yang mendukung.Hasil penelitian menunjukan sebagai berikut: (1) Pengembangan Internal, Memperkuat materi Museum dengan cara mengadakan kajian-kajian dan penelitian-penelitian. (2) Pengembangan Eskternal: Melakukan komunikasi yang baik dengan publik, Melakukan pengumpulan fakta/data, Analisis SWOT, Mengukur tingkat kepuasan pengunjung, Meningkatkan kerjasama, Mengoptimalkan media sosial.
\end{abstract}

ABSTRACT

This is an open access article under the $\underline{C C B Y-S A}$ license.

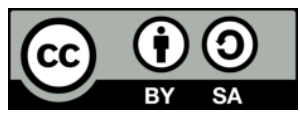

\section{Corresponding Author:}

Hana Pradita,

Program Studi Ilmu Komunikasi,

Universitas Ahmad Dahlan,

Email: hana@comm.uad.ac.id

\section{PENDAHULUAN}

Daerah Yogyakarta yang erat dengan predikat Istimewa, ternyata tidak pernah berhenti megembangkan keistimewaannya. Dikenal sebagai kota pelajar, tempat para pelajar dan mahasiswa untuk menuntut ilmu, mulai dari bangku sekolah dasar, menengah pertama, menengah atas, hingga perguruan tinggi baik yang dikelola oleh swasta maupun negeri. Kota Yogyakarta disebut sebagai kota budaya karena memiliki dua pusat budaya sebagai patokannnya, yaitu Kraton Kasultanan dan Pura Pakualaman. Dari kedua pusat budaya tersebut, Yogyakarta merupakan daerah yang kaya akan seni dan budaya(Keesing, 2014). Yogyakarta juga menjadi daya tarik wisata karena merupakan ikon dari kebudayaan Jawa yang kaya akan pesona, dipandang pula sebagai daerah potensial dengan posisinya yang strategis. Pendapatan perkapita penduduk Yogyakarta yang terus meningkat seiring dengan berkembangnya sektor pariwisata, menjadikan daya serap pasar lokal juga sangat besar. Didukung oleh infrastruktur yang terus ditingkatkan oleh pemerintah setempat, Yogyakarta mempunyai potensi pasar yang sangat baik. Daerah potensial sebagai pertumbuhan kawasan bisnis yang prospektif, salah satunya di sektor wisata sejarah dan budaya. Banyak potensi wisata di Yogyakarta yang bermunculan setiap tahunnya yang tersebar di berbagai wilayah atau kecamatan, terbagi dalam beberapa sektor wisata diantaranya bahari, religi atau budaya, ekowisata dan event wisata (Sefira Ryalita Primadany, Mardiyono, 2013).

Meseum merupakan salah satu cagar budaya. Dalam Undang-Undang Republik Indonesia No. 11 Tahun 2010 tentang cagar budaya pada ayat 1 dijelaskan bahwa cagar budaya adalah warisan budaya bersifat 
kebendaan berupa benda cagar budaya, bangunan cagar budaya, struktur cagar budaya, situs cagar budaya, dan kawasan cagar budaya di darat maupun di air yang perlu dilestarikan keberadaannya karena memiliki nilai penting bagi sejarah yaitu, Ilmu Pendidikan, Ilmu Pengetahuan, dan Ilmu Agama. Museum sebagai tujuan wisata yang umum di berbagai daerah wajib berupaya untuk tidak tertinggal dalam persaingan tersebut. Selain berfungsi sebagai lembaga budaya, museum juga ikut berkompetisi dengan penyedia jasa wisata lainnya terutama dalam menciptakan suasana menarik dan memberikan pengalaman berkesan bagi pengunjung. Museum yang berada di Yogyakarta sangat beragam, salah satunya adalah Museum Benteng Vredeburg. Tujuan museum ini didirikan untuk mengenang lima puluh tahun masa Kebangkitan Nasional dan mengenang sejarah perjuangan Bangsa Indonesia. Museum Benteng Vredeburg adalah merupakan salahsatu museum yang mempunyai koleksi-koleksi tentang sejarah perjuangan bangsa atau rakyat Indonesia. Museum Benteng Vredeburg sangat mempunyai perannan penting bagi dunia pendidikan dan untuk semua pengunjung yang berkeinginan untuk mengetahui prihal sejarah perjuangan rakyat dan bangsa Indonesia, sebagai museum yang menyimpan koleksi-koleksi serta bukti perjuangan rakyat Indonesia, meskipun demikian, masih banyak museum yang ditemukan di Yogyakarta yang belum diimbangi dengan pemahaman masyarakat luas tentang museum yang masih sangat terbatas(Kusrianto, 2007).

Museum yang baik pasti memberikan suasana belajar yang lebih baik santai dan terasa tidak terlalu formal. Media informasi yang disajikan oleh museum pada umumnya lebih beragam sehingga tidak menjemukan. Jika penjelasan ini telah memberikan gambaran peran museum yang sangat strategis sebagai sarana pendidikan dan pembelajaran, yaitu bentuk pembelajaran dan pendidikan apa yang dapat diberikan oleh museum. Museum Benteng Vredeburg juga harus memiliki pengelolaan yang bagus agar supaya bisa melakukan pengelolaan museum dengan secara apik. Untuk itu diperlukanlah suatu manajemen yang bisa memperbaiki dan membangun image museum dan supaya dapat menarik wisatawan mau mengunjungi museum tersebut agar bisa mempelajari nilai-nilai yang ada di dalamnya (Mussardo, 2019).

Berdasarkan dari latar belakang di atas maka yang melakukan penelitian tentang Strategi Pengembangan Museum Benteng Vredeburg Sebagai Media Komunikasi Pendidikan. Sebuah penelitian itu yang memiliki tujuan agar bisa mengetahui bagaimana strategi yang dijalankan oleh pihak pengelola Museum Benteng Vredeburg sebagai media komunikasi pendidikan (Watie, 2016).

\section{METODE}

Jenis penelitian yang akan digunakan dalam penelitian ini adalah studi kasus kualitatif dengan menggunakan pendekatan studi kasus (case study). Penelitian ini memusatkan diri secara intensif pada satu obyek tertentu yang mempelajarinya sebagai suatu kasus. Data studi kasus dapat diperoleh dari semua pihak yang bersangkutan, dengan kata lain dalam studi ini dikumpulkan dari berbagai sumber (Sugiyono, 2016).

Lokasi yang akan dijadikan penelitian yaitu Museum Benteng Vredeburg Jl. Margo Mulyo No.6, Ngupasan, Gondomanan, Kota Yogyakarta, Daerah Istimewa Yogyakarta. Dimulai pada bulan Maret - Agustus 2019 di Museum Benteng Vredeburg Yogyakarta. Dalam penelitian ini pengumpulan informasi diperoleh dari pihak- pihak yang ditunjuk untuk membagikan info tentang latar belakang dan keadaan yang sesungguhnya dari tempat yang akan dilakukannya penelitian. Sehingga data yang dihasilkan akurat, informan penelitian yang terpilih pada penelitian ini menggunakan teknik purposive, yang mana informan penelitian dipilih secara sengaja oleh peneliti berdasarkan kriteria dan pertimbangan tertentu.

Mengumpulkan data dengan mengajukan pertanyaan kepada Agus S. S.Pd. MA selaku Koordinator Perencanaan \& Program Museum Benteng Vredeburg Yogyakarta dan tujuan wawancara ini supaya peneliti mengetahui strategi pengembangan apa yang digunakan oleh Museum Benteng Vredeburg sebagai media komunikasi pendidikan. Teknik yang dilakukan dalam penelitian kualitatif adalah wawancara secara mendalam agar peneliti bisa memperoleh data yang dibutuhkan. Pengamatan secara langsung atau tidak langsung dalam kegiatan yang berada di objek penelitian yang bertujuan untuk mengidentifikasi hal-hal dan mencatat data-data terkait dengan penelitian. Mengumpulkan data dengan memanfaatkan buku-buku, literatur, laporan-laporan dan pustaka lain yang terkait.

\section{HASIL DAN PEMBAHASAN}

Penelitian ini berjudul STRATEGI PENGEMBANGAN MUSEUM BENTENG VREDEBURG YOGYAKARTA SEBAGAI MEDIA KOMUNIKASI PENDIDIKAN yaitu dalam hal ini peneliti akan memaparkan analisis dan penyajian data yang telah didapat yang berkaitan dengan strategi pengembangan Museum Benteng Vredeburg Yogyakarta sebagai media komunikasi pendidikan. Data yang diperoleh peneliti didapatkan dari hasil observasi, wawancara, dan dokumentasi yang dilakukan disekitar lingkungan penelitian yang sekiranya dapat mendukung penelitian. Peneliti melakukan observasi ke lokasi penelitian pada tanggal 9 April 2019. Berdasarkan hasil beberapa informan yaitu wawancara pertama kali dan kedua kalinya dilakukan pada tanggal 5 Mei 2019 dan 21 Mei 2019 dimana peneliti kali ini mewawancarai informan yang bernama 
Agus S. S.Pd, MA beliau sebagai Koor. Perencanaan dan Program. Selain itu peneliti juga melakukan wawancara pada tanggal 25 Mei 2019 untuk yang ketiga kalinya yaitu mewawancarai para pengunjung yang berkunjung ke dalam Museum Benteng Vredeburg Yogyakarta. Berikut ini peneliti akan memaparkan hasil penelitiannya dari informan yang sudah di wawancarai dan akan dijelaskan sebagai berikut.

Analisis Situasi (SWOT)

Sebelum merencanakan strategi pengembangan, analisis mengenai situasi dan pengembangan yang terjadi di Museum Benteng Vredeburg Yogyakarta harus dilakukan di internal dan eksternal. Analisis situasi ini dikenal dengan analisi SWOT, yaitu analisis tentang kekuatan dan kelemahan yang dimiliki oleh Museum Benteng Vredeburg, serta peluang dan ancaman yang dihadapi oleh Museum Benteng Vredeburg. Dengan demikian dapat diketahui strategi pengembangan apa saja yang di megunakan sehingga mampu meminimalisir kekurangan dari penyelenggaraan dan penyajian, dan apa saja peluang produk dalam upaya merebut pangsa pasar serta apa saja ancaman yang menghadang produk. "Ya, disini kita menggunakan beberapa analisis SWOT, untuk mengetahui strategi pengembangan Museum seperti kekurangan, kelemahan, peluang, serta ancaman" (Agus S. S.Pd, MA, Koor. Perencanaan dan Program, 5 Mei 2019)

Implementasi Strategi

Adapun untuk tahap perencanaan atau (planning), untuk semua informasi-informasi yang sudah dikumpulkan untuk menentukan suatu keputusan atau untuk merumuskan suatu bentuk kegiatan dan program yang akan di laksanakan. Sampai pada tahap perencanaan atau (planning) yaitu harus bisa menentukan sasaran dari kegiatan yang dilakukan. Pelayanan kepada pengunjung harus selalu diperhatikan dan di amati oleh seluruh karyawan Museum Benteng Vredeburg Yogyakarta, jika pelayanan terhadap pengunjung diberikan secara semaksimal mungkin maka akan terkesan sangat baik Museum Benteng Vredeburg Yogyakarta dimata para pengunjung akan semakin bertambah dengan perkembangan-perkembangan Musuem itu sendiri. Pelayanan yang diberikan oleh pihak Museum Benteng Vredeburg Yogyakarta terhadap pengunjung yaitu pelayanan yang sangat baik dan ramah, yakni: "Pelayanan yang kami berikan terhadap pengunjung sangatlah baik dan ramah, sehingga para pengunjung merasa puas setelah mengunjungi Museum Beneteng Vredeburg Yogyakarta. Apabila pengunjung merasa puas dengan pelayanan yang kami berikan maka secara tidak langsung mereka akan mempromosikan Musuem Benteng Vredeburg Yogyakarta ke khalayak umum" (Agus S. S.Pd, MA, Koor. Perencanaan dan Program, 5 Mei 2019). Apabila sudah di tentukan sebuah sasaran dan kegiatan, maka tahapan selanjutnya adalah memberikan pelayanan terhadap para pengunjung secara baik atau semaksimal mungkin dan evaluasi. Mengevaluasi adalah merupakan salah satu prosesi pengukuran dari hasil yang telah didapat atau diperoleh yang telah dilakukan dengan rancangan suatu kegiatan, sumber menjadi suatu pilihan prosedur yang sangat tepat untuk memperoleh suatu tujuan yang telah dipatenkan sebelumnya. Untuk menilai hasil yang sudah diperoleh apakah sudah sama dengan yang telah dirancang dan sudah sama dengan tujuan pengembangan Museum Benteng Vredeburg Sebagai Media Komunikasi Pendidkan. Selain itu evaluasi yang dilakukan agar mendapatkan langkah yang lebih baik untuk ke depannya dari sebelumnya. "Kita selalu mengadakan rapat bulanan dan evaluasi setiap ada kegiatan, supaya kita bisa mengetahui apa saja kekurangan yang ada di setiap kegiatan yang kita selengagarakan" (Agus S. S.Pd, MA, Koor. Perencanaan dan Program, 5 Mei 2019).

\section{KESIMPULAN (10 PT)}

Berdasarkan dari hasil penelitian dan pembahasan yang sudah diuraikan sebelumnya, strategi pengembangan museum benteng vredeburg yogyakarta sebagai media komunikasi pendidikan sebagai berikut: Pengembangan Internal

Memperkuat materi Museum dengan cara mengadakan kajian-kajian, penelitian-penelitian sejauh mana materi yang di persiapakan dan betul-betul menjadi hal yang sangat dibutuhkan untuk masyarakat sehingga menjadi penguatan di dalam esensinya atau di dalam materinya.

Pengembangan Eksternal

Melakukan Komunikasi Dengan Publik Pihak Museum Benteng Vredeburg Yogyakarta mewujudkan jalinan komunikasi yang apik kepada publiknya. Komunikasi Museum Benteng Vredeburg Yogyakarta menggunakan komunikasi internal dan eskternal, komunikasi secara internal dilakukan dengan cara berinteraksi secara langsung dengan para wisatawan saat wisatawan mengunjungi Museum. Mengoptimalkan media sosial seperti, media cetak merupakan sebagai bentuk barang yang dicetak digunakan sebagai saranan penyampaian pesan seperti surat kabar, brosur, leaflet, buletin, baliho dan lain sebagainya. 


\section{REFERENSI}

Azizah, A., \& Adawia, P. R. (2018). strategi pemasaran. Cakrawala - Jurnal Humaniora. https://doi.org/10.31294/JC.V18I2.4117

Hetherington, K. (2006). Museum. Theory, Culture \& Society. https://doi.org/10.1177/0263276406023002107

Keesing, R. (2014). Teori-Teori Tentang Budaya. Antropologi Indonesia. https://doi.org/10.7454/ai.v0i52.3313

Kusrianto, A. (2007). Pengantar Desain Komunikasi Visual. In Pengantar Desain Komunikasi Visual.

Mussardo, G. (2019). Pemasaran. Statistical Field Theor. https://doi.org/10.1017/CBO9781107415324.004

Nurmadiah, N. (2016). MEDIA PENDIDIKAN. Al-Afkar: Jurnal Keislaman \& Peradaban. https://doi.org/10.28944/afkar.v5i1.109

Reza, F. (2016). Strategi promosi penjualan. Jurnal Kajian Komunikasi.

Sefira Ryalita Primadany, Mardiyono, R. (2013). Analisis Strategi Pengembangan Pariwisata Daerah. Administrasi Publik.

Sugiyono. (2016). Memahami Penelitian Kualitatif. Bandung: Alfabeta.

Watie, E. D. S. (2016). Komunikasi dan Media Sosial (Communications and Social Media). Jurnal The Messenger. https://doi.org/10.26623/themessenger.v3i2.270 